\title{
Autoimmune/Inflammatory Arthritis Associated Lymphomas: Who Is at Risk?
}

\author{
Sujani Yadlapati ${ }^{1}$ and Petros Efthimiou ${ }^{1,2}$ \\ ${ }^{1}$ Rheumatology Division, New York Methodist Hospital, Brooklyn, NY 11215, USA \\ ${ }^{2}$ Weill Cornell Medical College, New York, NY 10065, USA \\ Correspondence should be addressed to Petros Efthimiou; petrosefthimiou@gmail.com
}

Received 17 March 2016; Revised 17 May 2016; Accepted 25 May 2016

Academic Editor: Yves Renaudineau

Copyright (c) 2016 S. Yadlapati and P. Efthimiou. This is an open access article distributed under the Creative Commons Attribution License, which permits unrestricted use, distribution, and reproduction in any medium, provided the original work is properly cited.

Specific autoimmune and inflammatory rheumatic diseases have been associated with an increased risk of malignant lymphomas. Conditions such as rheumatoid arthritis (RA), primary Sjögren's syndrome (pSS), systemic lupus erythematosus (SLE), dermatomyositis, and celiac disease have been consistently linked to malignant lymphomas. Isolated cases of lymphomas associated with spondyloarthropathies and autoinflammatory diseases have also been reported. Direct association between autoimmunity and lymphomagenesis has been reinforced by large epidemiological studies. It is still uncertain whether disease specific determinants or phenotypic or treatment related characteristics increase likelihood of lymphomagenesis in these patients. For example, recent literature has indicated a positive correlation between severity of inflammation and risk of lymphomas among RA and Sjögren's syndrome patients. It is also debated whether specific lymphoma variants are more commonly seen in accordance with certain chronic autoimmune arthritis. Previous studies have revealed a higher incidence of diffuse large B-cell lymphomas in RA and SLE patients, whereas pSS has been linked with increased risk of mucosa-associated lymphoid tissue lymphoma. This review summarizes recent literature evaluating risk of lymphomas in arthritis patients and disease specific risk determinants. We also elaborate on the association of autoimmune arthritis with specific lymphoma variants along with genetic, environmental, and therapeutic risk factors.

\section{Introduction}

Malignant lymphomas, particularly non-Hodgkin's lymphomas (NHL), are among the most commonly diagnosed malignancies in the United States [1]. One of the established associations is the occurrence of lymphomas in a setting of chronic inflammation. In the past decades, a higher incidence of lymphomas has been reported in patients with a range of chronic autoimmune and inflammatory rheumatic diseases. These ailments include rheumatoid arthritis (RA), systemic lupus erythematosus (SLE), primary Sjögren's syndrome (pSS), dermatomyositis, and celiac diseases. Isolated cases of malignant lymphomas have also been reported in patients with spondyloarthropathies such as psoriatic arthritis and ankylosing spondylitis, as well as chronic autoinflammatory arthritis such as Still's disease and systemic juvenile idiopathic arthritis. A higher predilection for malignant lymphomas has been seen among these patients when compared to the general population. This association has been widely established by a multitude of population based epidemiological studies across the world. However, the level of risk reported across the globe in autoimmune arthritis patients is not universal. This in turn raises the issue of whether the risk of lymphoma applies equally to all the patients diagnosed with the abovementioned rheumatic conditions.

Over the past decade, the pathogenesis of lymphoma in autoimmune diseases has been vastly explored; however, the exact biology behind the process is yet to be completely understood. Several plausible hypotheses have been suggested based on observational studies. These studies have proposed an increased risk of lymphomas in patients with immune dysregulation, patients receiving immunosuppressive drugs, or those who have been exposed to risk factors such as smoking or unknown environmental factors. It is also imperative to understand the variability in lymphomagenesis in rheumatic patients with different racial and genetic profiles. Another reason behind the inconsistency in risk estimates is that earlier and smaller studies reported higher 
risk levels compared to the more recent population based studies which have been larger $[2,3]$. Data from the recent studies also supports the notion that increased lymphoma risk may be restricted to one or two specific lymphoma subtypes and to patients with particular determinants of immune mediated disease. One such established association is the relationship between disease intensity in RA and development of lymphoma, diffuse large B-cell lymphoma (DLBCL) in particular [4].

In this review, we aim to summarize the risk of lymphomas in specific autoimmune/inflammatory arthritis. Alternatively, we elaborate on the association of autoimmune arthritis with specific lymphoma variants along with disease specific, genetic, environmental, and therapeutic risk factors that can potentially be implicated in the pathogenesis of lymphoma.

\section{Methodology}

Online search was performed using the keywords such as "autoimmune arthritis" "inflammation", "lymphomagenesis", and "lymphoma". This paper was written after reviewing fulltext articles written in English found on PubMed. Inclusion criteria for studies included in this review are those that have been published in the past 25 years. Studies included to show an association between autoimmune arthritis and lymphomagenesis met the following criteria: (1) case control/cohort study; (2) autoimmune arthritis, specifically rheumatoid arthritis (RA), systemic lupus erythematosus (SLE), Sjögren's syndrome, dermatomyositis, polymyositis, ankylosing spondylitis, and psoriatic arthritis; (3) lymphoma (NHL or HL) as an outcome of interest; (4) relative risk (RR), standardized incidence ratio (SIR), odds ratio (OR), or hazard ratio (HR) with 95\% confidence intervals (CIs). Articles have been included in this review on the basis of their relevance.

\section{Risk of Autoimmune Arthritis Associated Lymphoma}

Traditionally, lymphomas are classified as non-Hodgkin's lymphoma (NHL) and Hodgkin's lymphoma. NHL accounts for almost $90 \%$ of all cases whereas Hodgkin's lymphoma comprises the remaining 10\% [5]. NHL is further classified into T-cell and B-cell neoplasm based on the cell of origin. Here, we bring forth several population based studies evaluating increased risk of both NHL and HL in patients with a range of rheumatologic conditions (Table 1). It is evident that the magnitude of risk varies considerably among the studies. It is important to note that risk of lymphoma reported in each study is subject to variation depending on the population size and the population being studied. Earlier studies with smaller study population have reported higher risk estimates with a wide confidence interval when compared to the larger population based studies that have been published in the recent years. As per the published literature, the highest relative risk of lymphoma is associated with Sjögren's syndrome followed by RA and SLE. Relatively lower level of risk has been seen in patients with inflammatory myositis. Minimal risk if at all has been seen in patients with ankylosing spondylitis and psoriasis. Once again, this emphasizes the role of disease specific risk. A variation in the level of risk has been seen among patients in USA and countries such as Denmark or Sweden. This in turn raises the issue of population specific risk of lymphoma in these rheumatic conditions and implications of genetic and environmental influences on lymphomagenesis.

\section{Arthritis Specific Lymphoma Variants}

With newly emerging data from large pooled studies, it has become exceedingly evident that specific lymphoma subtypes are more commonly associated with particular types of autoimmune or inflammatory arthritis (Table 2). These NHL subtypes arise from singular stages of lymphocyte maturation. Therefore, association between specific autoimmune arthritis and corresponding NHL subtypes could lead to a superior understanding of mechanisms involved in lymphomagenesis. And, among these subclasses of arthritis patients, individual risk factors predispose the patient to a higher likelihood of developing lymphoma. This area has been further elaborated in the later sections of this paper.

A well known example of this is the strong association between patients with rheumatoid arthritis and diffuse large B-cell lymphoma (DLBCL). In a study conducted by Baecklund and associates, $67 \%$ of all RA/NHL cases (22 patients among 33 RA/NHL patients) were DLBCLs, compared to 30$40 \%$ of NHLs in the general population [6]. Similarly, in a case controlled study of 378 RA associated lymphomas, a high proportion of DLBCL was noted more than any other lymphoma subtype [4]. Similar findings were also described in a population based case control study in Denmark and Sweden enrolling 3055 NHL patients and 3187 matched control subjects [7]. Additionally, a stronger association of DLBCL with high disease activity in RA patients was also reported [7]. More comprehensive description of these RA associated DLBCLs has revealed that vast majority are of the nongerminal center (GC)/activated B-cell (ABC) subtype [8, 9]. Further evidence for the role of $B$ cells in the development of RA-DLBCL came from a study investigating the expression of APRIL, a cytokine essential for B-cell proliferation and development [10]. In this study, expression of APRIL was investigated in DLBCL tissue obtained from RA and SLE patients and compared to tissue obtained from DLBCL patients with no obvious inflammatory disease [10]. Higher expression of APRIL was detected in a subset of RA patients with high disease activity compared to RA patients with low disease activity. Similarly, higher expression of this cytokine was seen in SLE and RA patients when compared to those without an inflammatory disease [10].

Conversely, extranodal marginal zone B-cell lymphoma of the mucosa-associated lymphoid tissue (MALT lymphoma) is the most common lymphoma subtype associated with SS. This variant of lymphoma commonly affects the salivary glands and is associated with a good prognosis. This striking association of MALT lymphomas, particularly involving the parotid gland, has been further elaborated in numerous clinical studies [54, 55]. A 28-fold increase in risk of MALT lymphoma was described in a population based 
TABLE 1: Studies exploring risk of lymphomas in patients with RA, SLE, Sjögren's syndrome, inflammatory arthritis, and spondyloarthropathies.

\begin{tabular}{|c|c|c|c|c|c|c|}
\hline Author & Year & Country & Disease & Population $(n / N)$ & Variant & RR/SIR/OR (CI) \\
\hline Thomas et al. [11] & 2000 & Scotland & RA & $\begin{array}{l}17 / 26,623 \\
10 / 26,623\end{array}$ & $\begin{array}{l}\mathrm{HD}(\mathrm{SIR}) \\
\text { NHL }\end{array}$ & $\begin{array}{l}3.85(2.2,6.2) \\
2.13(1.7,2.6)\end{array}$ \\
\hline Mariette et al. [12] (TNFI) & 2011 & UK & RA & $18 / 30,000$ & NHL & $1.07(0.6,1.7)$ \\
\hline Ekström et al. [13] & 2003 & Sweden & RA & $\begin{array}{l}77 / 76,527 \\
18 / 30,000\end{array}$ & $\begin{array}{l}\mathrm{HD} \\
\mathrm{NHL}\end{array}$ & $\begin{array}{c}3.06(2.4,3.8) \\
1.89(1.7,2.1)\end{array}$ \\
\hline Abásolo et al. [14] & 2008 & $\begin{array}{l}\text { Southern } \\
\text { Europe }\end{array}$ & RA & 3/789 & NHL & $5.4(1.1,15.7)$ \\
\hline Wolfe and Michaud [15] & 2004 & USA & RA & $\begin{array}{c}4 / 13,869 \\
42 / 13,869\end{array}$ & $\begin{array}{l}\mathrm{HD} \\
\mathrm{NHL}\end{array}$ & $\begin{array}{l}3.0(1.3,6.8) \\
1.7(1.3,2.2)\end{array}$ \\
\hline Hemminki et al. [16] & 2008 & Sweden & RA & $\begin{array}{c}35 / 42,262 \\
280 / 42,262\end{array}$ & $\begin{array}{l}\mathrm{HD} \\
\mathrm{NHL}\end{array}$ & $\begin{array}{l}4.05(2.8,5.6) \\
2.34(2.1,2.6)\end{array}$ \\
\hline Anderson et al. [17] & 2009 & USA & RA & $\begin{array}{l}1157 \text { cases/3289 } \\
\text { controls }\end{array}$ & NHL & OR $1.2(1.1-1.3)$ \\
\hline Askling et al. [18] & 2009 & Sweden & RA & $26 / 26,981$ & $\mathrm{HD}$ & $2.7(1.8-4.1)$ \\
\hline Parikh-Patel et al. [19] & 2009 & USA & RA & $325 / 84,475$ & $\begin{array}{l}\text { NHL - Men, } \\
\text { women }\end{array}$ & $\begin{array}{l}2.1(1.7,2.5) \\
1.4(1.2,1.6)\end{array}$ \\
\hline Hellgren et al. [20] & 2010 & Sweden & RA & 19 cases $/ 53$ controls & $\mathrm{HD}$ & OR $1.8(1.0-3.0)$ \\
\hline Chen et al. [21] & 2010 & Taiwan & RA & $\begin{array}{c}1 / 23,644 \\
59 / 23,644\end{array}$ & $\begin{array}{l}\mathrm{HD} \\
\mathrm{NHL}\end{array}$ & $\begin{array}{c}1.76(1.5,2.2) \\
3.54(3.45,3.63)\end{array}$ \\
\hline Mercer et al. [22] & 2013 & UK & RA & $16 / 3771$ & NHL & $3.12(1.8,5.1)$ \\
\hline Dreyer et al. [23] & 2013 & Denmark & RA & $5 / 3812$ & NHL & $2.27(0.9,5.5)$ \\
\hline Anderson et al. [17] & 2009 & USA & SS & 142 cases $/ 255$ controls & NHL & $1.9(1.5-2.3)$ \\
\hline Zhang et al. [24] & 2010 & China & SS & $8 / 1320$ & NHL & $48.1(20.7-94.8)$ \\
\hline Solans-Laqué et al. [25] & 2011 & Spain & SS & $11 / 244$ & NHL & $15.6(8.7-28.2)$ \\
\hline Weng et al. [26] & 2012 & Taiwan & SS & $277 / 7852$ & $\begin{array}{l}\text { NHL - Men } \\
\text { NHL- Women }\end{array}$ & $\begin{array}{l}3.1(0.6-9.0) \\
7.1(4.2-10.3)\end{array}$ \\
\hline Johnsen et al. [27] & 2013 & Norway & SS & $7 / 443$ & NHL & $9(7.1-26.3)$ \\
\hline Liang et al. [28] & 2014 & Meta-analysis & SS & 14 studies & Lymphomas & $13.8(8.5-19.0)$ \\
\hline Feltelius et al. [29] & 2003 & Sweden & AS & $12 / 6621$ & Lymphomas & $1.3(0.9-1.9)$ \\
\hline Shibata et al. [30] & 2004 & Japan & AS & NA/3262 & Lymphomas & $2.8(1.4-5.6)$ \\
\hline Becker et al. [31] & 2005 & Germany & AS & 710 cases/controls & Lymphomas & $3.0(0.1-29)$ \\
\hline Askling et al. [32] & 2006 & Sweden & AS & $\begin{array}{c}50,615 \text { cases } / 92,928 \\
\text { controls }\end{array}$ & Lymphomas & $1.0(0.6-1.7)$ \\
\hline Mellemkjaer et al. [33] & 2008 & Denmark & AS & $\begin{array}{c}25,941 \text { cases } / 58,551 \\
\text { controls }\end{array}$ & Lymphomas & $1.1(0.6-1.8)$ \\
\hline Anderson et al. [17] & 2009 & USA & AS & $\begin{array}{l}33,721 \text { cases } / 122,531 \\
\text { controls }\end{array}$ & Lymphomas & $1.1(0.7-1.5)$ \\
\hline Rohekar et al. [34] & 2008 & Canada & PsA & NA/665 & Lymphomas & $0.7(0.3-1.8)$ \\
\hline Gross et al. [35] & 2014 & USA & PsA & $3 / 2977$ & Lymphomas & $0.4(0.1-1.2)$ \\
\hline Nived et al. [36] & 2001 & Sweden & SLE & $2 / 116$ & NHL & $11.63(1.40,42.0)$ \\
\hline Cibere et al. [37] & 2001 & Canada & SLE & $4 / 297$ & NHL & $7(1.9,8)$ \\
\hline Björnådal et al. [38] & 2002 & Sweden & SLE & $32 / 5715$ & NHL & $2.86(1.96,4.04)$ \\
\hline Tarr et al. [39] & 2007 & Hungary & SLE & $2 / 860$ & NHL & $3.50(0.4,12.5)$ \\
\hline Parikh-Patel et al. [40] & 2008 & USA & SLE & $96 / 30478$ & NHL & $2.74(2.22,3.34)$ \\
\hline Anderson et al. [17] & 2009 & USA & SLE & 129 cases/285 controls & NHL (OR) & $1.5(1.2-1.9)$ \\
\hline Kang et al. [41] & 2010 & Korea & SLE & $3 / 914$ & NHL & $15.4(2.9-37.7)$ \\
\hline Chen et al. [21] & 2010 & Taiwan & SLE & NA/11763 & Lymphomas & $7.3(7.0-7.6)$ \\
\hline Dreyer et al. [42] & 2011 & Denmark & SLE & $4 / 576$ & NHL & $5.0(1.9-13.3)$ \\
\hline
\end{tabular}


TABLE 1: Continued.

\begin{tabular}{|c|c|c|c|c|c|c|}
\hline Author & Year & Country & Disease & Population $(n / N)$ & Variant & RR/SIR/OR (CI) \\
\hline Bernatsky et al. [43] & 2013 & Scotland & SLE & $76 / 16409$ & $\begin{array}{c}\text { NHL } \\
\text { HL }\end{array}$ & $\begin{array}{l}4.4(3.5-5.5) \\
2.3(0.9-4.7)\end{array}$ \\
\hline Hill et al. [44] & 2001 & $\begin{array}{c}\text { Sweden, } \\
\text { Denmark, and } \\
\text { Finland }\end{array}$ & Dermatomyositis & NA/618 & NHL & $3.6(1.2,11.1)$ \\
\hline Stockton et al. [45] & 2001 & Scotland & Dermatomyositis & $\begin{array}{l}2 / 50 \\
1 / 50\end{array}$ & $\begin{array}{l}\text { NHL } \\
\mathrm{HL}\end{array}$ & $\begin{array}{c}13.3(1.6,48) \\
28.4(0.7,157.9)\end{array}$ \\
\hline Hill et al. [44] & 2001 & $\begin{array}{c}\text { Sweden, } \\
\text { Denmark, and } \\
\text { Finland }\end{array}$ & Polymyositis & NA/914 & NHL & $3.7(1.7-8.2)$ \\
\hline Stockton et al. [45] & 2001 & Scotland & Polymyositis & $\begin{array}{l}2 / 40 \\
2 / 40\end{array}$ & $\begin{array}{c}\text { NHL } \\
\mathrm{HL}\end{array}$ & $\begin{array}{l}5(0.6,18.1) \\
31(3.8,112) \\
\end{array}$ \\
\hline
\end{tabular}

RA: rheumatoid arthritis; SLE: systemic lupus erythematosus; AS: ankylosing spondylitis; SS: Sjögren's syndrome; PsA: psoriatic arthritis; RR: relative risk; SIR: standardized incidence ratio; OR: odds ratio; CI: confidence interval; $n$ : number of cases of lymphoma; $N$ : study population; NA: not available.

TABLE 2: Autoimmune arthritis specific lymphoma variants.

\begin{tabular}{lcc}
\hline Disease & $\begin{array}{c}\text { Associated lymphoma } \\
\text { subtype }\end{array}$ & Reference \\
\hline $\begin{array}{l}\text { Rheumatoid arthritis } \\
\text { (RA) }\end{array}$ & $\begin{array}{c}\text { Diffuse large B-cell } \\
\text { lymphoma }\end{array}$ & {$[4,6,7]$} \\
& $\begin{array}{l}\text { (DLBCL) } \\
\text { Mucosa-associated }\end{array}$ & \\
$\begin{array}{l}\text { Primary Sjögren's } \\
\text { syndrome (pSS) }\end{array}$ & $\begin{array}{c}\text { lymphoid tissue (MALT) } \\
\text { Diffuse large B-cell } \\
\text { lymphoma (DLBCLs) }\end{array}$ & {$[35-37]$} \\
Systemic lupus & Diffuse large B-cell & {$[38,39]$} \\
erythematosus (SLE) & lymphoma (DLBCL) & \\
Inflammatory myositis & No specific association & \\
Psoriasis & T-cell lymphoma & {$[46,47]$} \\
\hline
\end{tabular}

case control study conducted by Smedby and colleagues [7]. On the other hand, when clinical features at presentation were evaluated in 33 patients with parotid MALT lymphoma, $46 \%$ of the patients had underlying SS [56]. Although an indisputable association already exists between SS and MALT lymphoma, a large number of DLBCL subtypes have also been reported in these patients $[54,55]$. DLBCL in patients with pSS may be de novo or a result of transformation of previously unrecognized low grade MALT lymphoma [57]. Development of overt MALT lymphoma starts with early unremitting antigenic autoimmune stimulation, clonal expansion of B cells, and acquisition of genetic aberrations $[58,59]$. Probable mechanism entails sequential progression from initial lymphoepithelial sialadenitis to acquirement of ectopic MALT tissue and further progressing to overt lymphoma.

Both cases of HL and NHL have been reported among SLE patients. However, the most common NHL subtype reported in these patients is DLBCL [60]. Bernatsky et al. reported a similar finding in a multicenter international cohort study [61]. Stimulated lymphocytes play a role in the activated B-cell subtypes of DLBCL, further reiterating the notion that chronic inflammation might heighten lymphoma risk in diseases like SLE [60]. A potential explanation for increased risk of NHL in SLE is that discrete major histocompatibility complexes (MHC) haplotypes may predispose to both disorders [62]. Another plausible mechanism is a defective immune system resulting in abnormal B-cell activation due to chronic and persistent antigenic stimulation, cell-cycle deregulation, and impaired apoptosis, ultimately resulting in uninhibited cell proliferation, heightened humoral immune response, and increased risk of oncogene translocation [63]. The impaired immune response in SLE is characterized by accumulation of activated self-reactive B and T cells [64]. Studies evaluating the risk of NHL in psoriasis patients have reported an increased risk of T-cell lymphoma overall or mycosis fungoides $[46,47,65]$.

\section{Disease Specific Risk Factors of Lymphomas}

5.1. Rheumatoid Arthritis (RA) Associated Lymphomas. Increased risk of both NHL and HL has been reported in association with RA. There are however studies that have demonstrated variation in risk among RA patients. The strongest evidence indicating the correlation between disease activity and occurrence of lymphoma in RA patients was demonstrated by Baecklund and associates in a Swedish case control study [4]. 378 RA cases with lymphoma were compared to $378 \mathrm{RA}$ patients in a control group without lymphomas. Information on disease characteristics such as number of swollen and tender joints, ESR values, and physician's global assessment score was obtained from medical records along with the course of treatment from onset of RA till lymphoma development. 70-fold increased lymphoma risk was observed in those RA patients with the highest disease activity as determined by the clinical components mentioned above. This finding was further corroborated in a smaller cohort study evaluating 29 RA patients with lymphoma [15]. It was further concluded that it was high inflammatory activity among RA patients, rather than its treatment, that was the major determinant in the development of lymphoma [4]. Indicators of disease severity such as presence of Felty's syndrome, high erythrocyte 
sediment rate (ESR) values, and erosive joint disease have been coupled with lymphoma risk in RA patients $[66,67]$.

5.2. Sjögren's Syndrome (SS) Associated Lymphomas. Increased occurrence of NHL has been reported in patients with Sjögren's syndrome, particularly primary Sjögren's syndrome (pSS). Sjögren's syndrome is characterized by lymphocytic infiltration of exocrine glands. In a cohort study evaluating risk of NHL in SS, 676 patients with pSS and 709 patients with secondary Sjögren's syndrome were enrolled. A relative risk of 8.7 (95\% CI: 1.5-11) and 4.5 (95\% CI: $1.5-11$ ) was found in patients with primary and secondary form, respectively [68]. Numerous cohort and population based studies have established risk factors for Sjögren's syndrome associated lymphoma. Theander and colleagues proposed an increased risk of lymphoma in patients with followup period longer than 10 years [69]. In about $20-40 \%$ of the patients, the disease extends beyond exocrine glands. Epithelial lymphocytic invasion of the lung, liver, and kidneys or even immune complex mediated phenomena are evident in these patients. This subset of patients presents with major salivary gland enlargement and other features suggestive of extraglandular involvement such as lymphadenopathy, splenomegaly, peripheral neuropathy, and cutaneous lesions secondary to vasculitis $[55,69-71]$, all of which have been implicated with a higher risk of non-Hodgkin's lymphoma.

Lab findings such as cryoglobulinemia, low complement levels along with lymphopenia, and $\mathrm{M}$ components in serum or urine have also been suggested to contribute to higher risk of lymphomas [72]. Within the past 5 years, findings of severe glandular dysfunction, as identified by parotid scintigraphy, and ectopic germinal center structures, identified in minor salivary gland biopsies, at time of pSS diagnosis have also been proposed to play a role in lymphomagenesis $[73,74]$. Similarly, in an isolated study evaluating the role of CD4 cytopenia and low CD4+/CD8+ ratio, these factors were the dominant predictors of lymphoma risk [69]. A bulk of lymphomas occurring in pSS are extranodal marginal zone lymphomas of mucosa-associated tissue (MALT lymphomas), along with some cases of DLBCL. Immunosuppressive therapy associated lymphoma risk has been rarely reported in patients with SS [75].

5.3. Systemic Lupus Erythematosus (SLE) Associated Lymphomas. Numerous cohort and case control studies have reported variable risk of lymphoma among SLE patients. In a Swedish population based cohort study with 5715 hospitalized SLE patients, there was nearly a 3-fold increase (SIR $=2.86$, CI 95\%: 1.96-4.04) in the incidence of NHL during the observation period [38]. Similarly, in an international study, a cohort of SLE patients from 23 centers were followed up for an average of 8 years [76]. This study included 9547 patients with SLE. The data gathered revealed a 3- to 4-fold increase in risk of NHL (3.64, 95\% CI: 2.63-4.93). Disease related risk factors evaluated thus far include mean disease duration at the time of NHL diagnosis and disease severity. A mean disease duration of 12.4 years at diagnosis of NHL was also reported [77]. In a similar study, a mean duration of 17.8 years was reported by King and Costenbader [78].
Bernatsky and colleagues also identified a higher risk of SLE related lymphoma in males compared to female patients and this risk increased with older age. However, this finding was of no particular significance as these parameters were not different from those of the high risk group in the general population without SLE. Indicators of disease severity such as hematologic complications, involvement of the lungs, and sicca syndromes along with high SLE damage score have been implicated as predictors of lymphomas among this population [78-80]. On the other hand, studies have also demonstrated a relationship between exposure to medication and lymphoma development in these patients. A higher lymphoma risk in patients with exposure to cyclophosphamide and high cumulative steroids was seen in multisite SLE cohort analyses [77]. Alternatively, other studies reported negligible risk of treatment associated lymphomas in SLE patients [37]. Hence, role of immunosuppressive drugs in SLE related lymphoma does not seem to be crucial.

5.4. Polymyositis and Dermatomyositis Associated Lymphomas. Inflammatory myositis, particularly dermatomyositis, has been associated with a significant overall risk of malignancies. Lymphomas are among malignancies reported in this population. In the past, certain studies have reported up to 2- to 4-fold elevated risk of NHL in dermatomyositis patients [44, 81], while others failed to reveal any such association [45]. It was also concluded that the highest risk of malignancy in both polymyositis and dermatomyositis was at the time of diagnosis [44]. In a study conducted by Hill et al., four out of five NHL cases were diagnosed within the first year of follow-up or immediately preceding the diagnosis of myositis [44]. This in turn raises the question of whether the incidence of malignant lymphomas in these patients is a result of underlying inflammatory myositis or whether inflammatory myositis is merely a paraneoplastic phenomenon of underlying malignancy. More epidemiologic studies are needed to further clarify this association, as well as evaluate treatment related risk of lymphomas among these patients.

5.5. Spondyloarthropathies Associated Lymphomas. There is scarcity of data linking overall increased risk of lymphoproliferative malignancies with spondyloarthropathies, unlike RA and Sjögren's syndrome. Conflicting views have been put forth about direct association between lymphomas and psoriasis. However, most studies evaluating the risk of NHL in psoriasis patients have reported an increased risk of Tcell lymphoma overall or mycosis fungoides [46, 47, 65]. Similarly, Gelfand et al. reported an increase in risk of both HL and NHLs in 150,000 patients with mild psoriasis and 4000 patients with severe psoriasis [82]. A higher risk was seen in patients with severe disease (above 10-fold) when compared to the patients with milder disease (4fold). However, other studies have failed to show such an association. This discrepancy in the number of lymphoma cases reported is possibly due to potential inflation of risk in some studies as T-cell lymphomas may often mimic psoriasis and hence may be misclassified. 
TABLE 3: Selective studies evaluating therapy related risk of lymphoma in RA patients.

\begin{tabular}{|c|c|c|c|c|c|c|c|}
\hline Author & Year & Therapy & Disease & Sample population & $\begin{array}{l}\text { Measure of } \\
\text { risk }\end{array}$ & Comparison group & Risk \\
\hline \multirow{2}{*}{$\begin{array}{l}\text { Wolfe and } \\
\text { Michaud [48] }\end{array}$} & \multirow{2}{*}{2007} & $\begin{array}{l}\text { Inf., Etan., and } \\
\text { Ana. }\end{array}$ & RA & \multirow{2}{*}{19,591} & OR & $\begin{array}{l}\text { All RA patients not } \\
\text { on anti-TNF therapy }\end{array}$ & $\begin{array}{c}1.0(0.6,1.8) \\
P=0.875\end{array}$ \\
\hline & & $\begin{array}{l}\text { Anti-TNF therapy } \\
\text { plus MTX }\end{array}$ & RA & & OR & MTX therapy alone & $\begin{array}{c}1.1(0.6,2.0) \\
P=0.710\end{array}$ \\
\hline $\begin{array}{l}\text { Geborek et al. } \\
\text { [49] }\end{array}$ & 2005 & Inf. and Etan. & RA & $\begin{array}{c}757 \text { (anti-TNF group) } \\
\text { versus } 800 \\
\text { (conventional } \\
\text { treatment) }\end{array}$ & AHR & $\begin{array}{l}\text { Anti-TNF alpha naive } \\
\text { RA patients }\end{array}$ & $\begin{array}{c}5.0(0.9,27.9) \\
P=0.06\end{array}$ \\
\hline $\begin{array}{l}\text { Askling et al. } \\
{[50]}\end{array}$ & 2005 & $\begin{array}{l}\text { Inf., Etan., and } \\
\text { Ana. }\end{array}$ & RA & 4160 & ARR & $\begin{array}{l}\text { All RA patients/all } \\
\text { treatments }\end{array}$ & $1.1(0.6,2.1)$ \\
\hline $\begin{array}{l}\text { Setoguchi et } \\
\text { al. [51] }\end{array}$ & 2006 & $\begin{array}{l}\text { Inf., Etan., and } \\
\text { Ana. }\end{array}$ & RA & $\begin{array}{c}1152 \text { biologic users } \\
\text { versus } 7306 \text { MTX } \\
\text { users } \\
\end{array}$ & AHR & $\begin{array}{l}\text { RA patients with } \\
\text { MTX use only }\end{array}$ & $1.11(0.51,2.37)$ \\
\hline $\begin{array}{l}\text { Askling et al. } \\
{[18]}\end{array}$ & 2009 & $\begin{array}{l}\text { Inf., Etan., and } \\
\text { Ana. }\end{array}$ & RA & 6604 & ARR & $\begin{array}{c}\text { Anti-TNF alpha naive } \\
\text { RA patients }\end{array}$ & $1.35(0.82,2.11)$ \\
\hline \multirow{2}{*}{$\begin{array}{l}\text { Wolfe and } \\
\text { Michaud [52] }\end{array}$} & \multirow[b]{2}{*}{2004} & MTX & \multirow[b]{2}{*}{ RA } & \multirow[b]{2}{*}{18,572} & SIR & \multirow[b]{2}{*}{ General population } & $1.7(95 \%$ CI $0.9-3.2)$ \\
\hline & & $\begin{array}{c}\text { Infliximab and } \\
\text { etanercept }\end{array}$ & & & SIR & & 2.9 (95\% CI 1.7-4.9) \\
\hline $\begin{array}{l}\text { Buchbinder } \\
\text { et al. [53] }\end{array}$ & 2008 & MTX & RA & 459 & SIR & General population & $5.1(2.2-10.0)$ \\
\hline
\end{tabular}

Inf.: infliximab; Etan.: etanercept; Ana.: anakinra; RA: rheumatoid arthritis; MTX: methotrexate; ARR: adjusted relative risk; AOR: adjusted odds ratio; AHR: adjusted hazard ratio; SIR: standardized incidence ratio.

One other spondyloarthropathy linked to risk of lymphomagenesis is ankylosing spondylitis. Although most studies have not revealed a significant link between AS and lymphomas, Mullighan et al. reported almost a 3-fold higher risk of lymphoma (SIR 2.8; 95\% CI: 1.4-5.6) [83]. Despite few cases of positive association between AS and lymphomas, this connection can be refuted due to scarcity of data and lower magnitude of such relationship when compared to lymphoma risk in RA or SS.

\section{Therapy Related Risk of Lymphomas}

It has been debated for years whether immunosuppressive medication used to treat inflammatory diseases could carry an innate and subsequently amplified risk of lymphoma. These drugs include widely used disease modifying antirheumatic drugs (DMARDs) such as methotrexate (MTX) and azathioprine and biologic agents such as infliximab and etanercept. Several studies have explored the association between lymphoma and RA therapy (Table 3). However, inconsistent results have been reported in these studies. Incidence of MTX-LPD was assessed in 403 RA patients in a study conducted by Yoshida et al. [84]. Four out of the 403 RA patients being treated with MTX developed lymphomas. The patients who developed MTX-LPDs had significantly shorter disease duration and over half of them showed tumor regression following cessation of MTX [84], therefore highlighting the possibility of MTX related lymphomagenesis. Similar finding of MTX-LPD regression following treatment cessation was reported by Ikeda and associates in a rare case of gastric lymphoma in a RA patient [85]. Another noteworthy finding is the involvement of extranodal sites in $40-50 \%$ of MTX related LPD cases. Extranodal sites include gastrointestinal tract, skin, liver, lung, and kidney. In addition, several cases of MTX related EBV associated LPD have also been documented. It is a well recognized fact that patients with immunodeficiency, such as those on MTX therapy, have a high risk of developing lymphoma, and EBV is associated with pathogenesis of lymphomas. Approximately $30-50 \%$ of lymphomas in RA patients on MTX therapy are EBV positive [86, 87]. However, the precise role of methotrexate in lymphomagenesis is poorly understood and is yet to be validated. For example, several of these studies have not taken into account the effect of underlying disease, disease severity, and reasons for treatment. Most larger studies have reported negligible risk of lymphoma in RA patients on chronic MTX therapy [88]. The strong association between disease severity and propensity for antirheumatic treatment makes it hard to understand whether the disease severity and underlying pathology themselves contribute to lymphomagenesis or whether they are actually treatment related. Similarly, an association between azathioprine and lymphoma has been reported in patients with autoimmune diseases. However, a meta-analysis conducted by Kandiel et al. suggested a stronger role of underlying disease and a combination of factors with lymphomagenesis when compared to role of azathioprine [89].

Other non-DMARD therapies such as use of NSAIDs and systemic corticosteroids have also been suspected to play a role in lymphomagenesis. However, several cohort and case control studies revealed no significant association between use of NSAIDs and steroids and lymphoma risk. 
TNF antagonists are a commonly prescribed group of medications in RA patients. A number of cases of lymphomas were documented in several patients in the earlier trials of this class of medication [90, 91]. However, meta-analysis of observational data from registries as well as randomized controlled trials has failed to show a significant increase in the risk of lymphoma especially if a sufficiently large sample size was enrolled in the study with adequate follow-up period [92]. The current literature evaluating the role of medication related lymphomas in RA offers minimal insight secondary to limitations by potential confounding.

\section{Conclusion}

Link between autoimmune diseases and lymphomas has been validated by several population based studies in the past. In particular, studies exploring RA and Sjögren's syndrome associated lymphomas have brought forth a great deal of evidence to light. On the other hand, it still remains ambiguous why other autoimmune conditions, such as type 1 diabetes mellitus, multiple sclerosis, and sarcoidosis, do not present an amplified risk of lymphoma. Studies exploring risk of lymphoma in multiple sclerosis and diabetes mellitus have reliably shown no excess risk of lymphoma or hematologic malignancy [93-96]. A few cases of Hodgkin's lymphoma have been reported in patients with sarcoidosis. A large cohort study of 9000 sarcoidosis patients reported a twofold increased risk of lymphoma overall (SIR 1.9; 95\% CI: 1.32.7), with significantly increased risk of lymphoma confined to the initial four years of follow-up [97]. However, two other smaller cohort studies did not report such an association [98, 99]. Therefore, although the strength of association between increased risk of lymphoma and sarcoidosis remains weak, it cannot be completely excluded due to inadequate evidence.

Among patients with autoimmune arthritis, severity of disease and higher degree of inflammation have consistently been associated with increased risk of lymphoma. Another noteworthy fact is the display of different spectra of lymphomas in each variant of autoimmune arthritis, further emphasizing the notion that lymphomagenesis is probably disease specific. As mentioned earlier, DLBCL has been linked to both SLE and RA. This could potentially be a result of chronic activation of peripheral B cells leading to uncontrolled proliferation of clonal B-cell populations, ultimately resulting in a lymphoma. Also worthy of note, autoimmune disease associated lymphomas are overwhelmingly of Bcell type, the major exceptions being the intestinal T-cell lymphomas that arise in long-standing celiac disease and in association with infection with the retrovirus HTLV-1. The higher occurrence of B-cell type lymphomas in autoimmune diseases can perhaps be explained by the role of $\mathrm{B}$ cells at a cellular level. Functions of B cells include secretion of autoantibodies, autoantigen presentation, reciprocal interactions with $\mathrm{T}$ cells, secretion of inflammatory cytokines, and generation of ectopic germinal centers [100]. Through these mechanisms, B cells are involved both in pathogenesis of autoimmune diseases and in lymphomagenesis.

Alternate risk factors for lymphomagenesis include exposure to infectious agents and environmental factors such as smoking in addition to genetic susceptibility. Infectious agents linked to lymphomagenesis include Epstein-Barr virus (EBV), human immunodeficiency virus (HIV), hepatitis C virus $(\mathrm{HCV})$, and human T-cell lymphotropic virus-1 (HTLV1). Among these infectious agents, EBV and $\mathrm{HCV}$ are of particular interest. EBV demonstrates oncogenic potential by persisting in B cells and potentially transforming these cells. Several case reports have proposed a potential role of EBV in lymphomagenesis in patients with MTX-LPD among RA patients. Spontaneous regression of EBV positive lymphomas was witnessed in these cases following cessation of MTX therapy for RA. However, no increase in distribution of EBV positive lymphomas was seen in RA patients when compared to the lymphomas arising in the general population. HCV infection has also been implicated in the development of Bcell NHL. Pathogenic processes accountable for HCV related lymphoproliferative disorders remain ambiguous. Existing evidence supports a model in which chronic stimulation of B cells by antigens associated with HCV infection causes nonmalignant cell expansion that may evolve into B-cell NHL. Probable interactions between HCV and other viral agents such as HIV and EBV have also been investigated in development of lymphoproliferative disorders [101]. HCV has been found in a large proportion of salivary gland MALT lymphomas, particularly in areas endemic to this virus [56, 102].

Smoking is an independent risk factor in both lymphomas and autoimmune/inflammatory arthritis. Past studies have also linked smoking to specific variants of lymphomas. These variants include follicular lymphoma, T-cell lymphoma, and Hodgkin's lymphoma. Gibson et al. reported a $30 \%$ increase in risk of follicular lymphoma but not nonHodgkin's lymphoma (NHL) overall or other NHL subtypes $[103,104]$. Similarly, a relationship between smoking and amplified risk of T-cell lymphoma and Hodgkin's lymphoma has been suggested by Sergentanis and colleagues [105]. Previous literature has also shown an association between smoking and anti-citrullinated protein antibody-positive RA and SLE [106]. However, there is shortage of data linking smoking to RA associated lymphomas. This remains an area for further exploration in future studies. An alternative hypothesis linking RA and lymphoma risk is genetic susceptibility, along with environmental risk factors. In a registry based cohort study, evaluating the risk of lymphoma in family members of RA patients, there was marginal or no significant increase in risk of lymphoma among parents and siblings of the sample population [13]. These findings further corroborate the fact that increased lymphoma risk in RA patients is probably secondary to factors directly associated with disease or its treatment [13].

It remains unclear whether the clinical course of lymphomas complicating autoimmune arthritis is different from that of lymphomas occurring in the general population. In 2003, a Swedish study reported a median survival rate of 6 months in patients with RA/NHL [6]. On the other hand, a larger, more recent study of 65 RA lymphoma cases and 1500 non-RA lymphoma controls reported a hazard ratio of 0.60 (95\% CI: 0.37-0.98) [107]. This disparity in results makes it difficult to truly understand the clinical outcome 
of autoimmune disease associated lymphomas. However, the disparity in outcomes of the two abovementioned studies can be attributed to the variation in sample size as well as to the advances in lymphoma related diagnostic and treatment modalities. One such example is the emerging role of rituximab, a monoclonal anti-CD20 antibody that can be used in the treatment of lymphomas and autoimmune arthritis. A true grasp on this matter can only be obtained in the future following a thorough investigation using large population based studies.

Autoimmune rheumatic diseases and lymphocytic malignancies exhibit a bidirectional relationship. It is important to differentiate lymphomas that occur in the course of an autoimmune disease from a lymphoma presenting with paraneoplastic multisystemic involvement or autoimmune rheumatic manifestations. Several patients present with rheumatic manifestations month to years after the onset of lymphocytic malignancy [108]. Currently, it is also pertinent to conduct detailed molecular studies to determine the key pathogenic events in lymphomagenesis. It is also imperative to identify "triggers" or risks for malignant lymphomas in this population. This would help define algorithms to identify autoimmune arthritis patients with higher likelihood of lymphomagenesis. Quantifying level of risk in the target population prior to initiation of treatment will help us better understand the role of immunosuppressive therapy in lymphomagenesis. Additional research is needed to definitively state whether therapy in arthritis contributes to risk of lymphomas or alters the clinical course of malignant lymphomas in these patients.

\section{Competing Interests}

The authors have no competing interests regarding the publication of this paper.

\section{References}

[1] D. M. Parkin, "Global cancer statistics in the year 2000," The Lancet Oncology, vol. 2, no. 9, pp. 533-543, 2001.

[2] K. E. Smedby, E. Baecklund, and J. Askling, "Malignant lymphomas in autoimmunity and inflammation: a review of risks, risk factors, and lymphoma characteristics," Cancer Epidemiology Biomarkers and Prevention, vol. 15, no. 11, pp. 2069-2077, 2006.

[3] K. E. Smedby, J. Askling, X. Mariette, and E. Baecklund, "Autoimmune and inflammatory disorders and risk of malignant lymphomas-an update," Journal of Internal Medicine, vol. 264, no. 6, pp. 514-527, 2008.

[4] E. Baecklund, A. Iliadou, J. Askling et al., "Association of chronic inflammation, not its treatment, with increased lymphoma risk in rheumatoid arthritis," Arthritis \& Rheumatism, vol. 54, no. 3 , pp. 692-701, 2006.

[5] E. S. Jaffe, N. L. Harris, H. Stein, and J. W. Vardiman, Eds., Pathology and Genetics of Tumours of Hematopoietic and Lymphoid Tissues, IARC Press, Lyon, France, 2001.

[6] E. Baecklund, C. Sundström, A. Ekbom et al., "Lymphoma subtypes in patients with rheumatoid arthritis: increased proportion of diffuse large B cell lymphoma," Arthritis and Rheumatism, vol. 48, no. 6, pp. 1543-1550, 2003.
[7] K. E. Smedby, H. Hjalgrim, J. Askling et al., "Autoimmune and chronic inflammatory disorders and risk of non-Hodgkin lymphoma by subtype," Journal of the National Cancer Institute, vol. 98, no. 1, pp. 51-60, 2006.

[8] E. Baecklund, C. Backlin, A. Iliadou et al., "Characteristics of diffuse large B-cell lymphomas in rheumatoid arthritis," Arthritis and Rheumatism, vol. 54, no. 12, pp. 3774-3781, 2006.

[9] E. Baecklund, Y. Natkunam, C. Backlin et al., "Expression of the human germinal-centre-associated lymphoma protein in diffuse large B-cell lymphomas in patients with rheumatoid arthritis," British Journal of Haematology, vol. 141, no. 1, pp. 6972, 2008.

[10] B. Löfström, C. Backlin, T. Pettersson, I. E. Lundberg, and E. Baecklund, "Expression of APRIL in diffuse large B cell lymphomas from patients with systemic lupus erythematosus and rheumatoid arthritis," Journal of Rheumatology, vol. 38, no. 9, pp. 1891-1897, 2011.

[11] E. Thomas, D. H. Brewster, R. J. Black, and G. J. Macfarlane, "Risk of malignancy among patients with rheumatic conditions," International Journal of Cancer, vol. 88, no. 3, pp. 497502, 2000.

[12] X. Mariette, M. Matucci-Cerinic, K. Pavelka et al., "Malignancies associated with tumour necrosis factor inhibitors in registries and prospective observational studies: a systematic review and meta-analysis," Annals of the Rheumatic Diseases, vol. 70, no. 11, pp. 1895-1904, 2011.

[13] K. Ekström, H. Hjalgrim, L. Brandt et al., "Risk of malignant lymphomas in patients with rheumatoid arthritis and in their first-degree relatives," Arthritis \& Rheumatism, vol. 48, no. 4, pp. 963-970, 2003.

[14] L. Abásolo, E. Júdez, M. Á. Descalzo, I. González-Álvaro, J. A. Jover, and L. Carmona, "Cancer in rheumatoid arthritis: occurrence, mortality, and associated factors in a South European population," Seminars in Arthritis and Rheumatism, vol. 37, no. 6, pp. 388-397, 2008.

[15] F. Wolfe and K. Michaud, "Lymphoma in rheumatoid arthritis: the effect of methotrexate and anti-tumor necrosis factor therapy in 18,572 patients," Arthritis \& Rheumatism, vol. 50, no. 6, pp. 1740-1751, 2004.

[16] K. Hemminki, X. Li, K. Sundquist, and J. Sundquist, "Cancer risk in hospitalized rheumatoid arthritis patients," Rheumatology, vol. 47, no. 5, pp. 698-701, 2008.

[17] L. A. Anderson, S. Gadalla, L. M. Morton et al., "Populationbased study of autoimmune conditions and the risk of specific lymphoid malignancies," International Journal of Cancer, vol. 125, no. 2, pp. 398-405, 2009.

[18] J. Askling, E. Baecklund, F. Granath et al., "Anti-tumour necrosis factor therapy in rheumatoid arthritis and risk of malignant lymphomas: Relative risks and time trends in the Swedish Biologics Register," Annals of the Rheumatic Diseases, vol. 68, no. 5, pp. 648-653, 2009.

[19] A. Parikh-Patel, R. H. White, M. Allen, and R. Cress, "Risk of cancer among rheumatoid arthritis patients in California," Cancer Causes and Control, vol. 20, no. 6, pp. 1001-1010, 2009.

[20] K. Hellgren, K. E. Smedby, N. Feltelius, E. Baecklund, and J. Askling, "Do rheumatoid arthritis and lymphoma share risk factors?: A comparison of lymphoma and cancer risks before and after diagnosis of rheumatoid arthritis," Arthritis \& Rheumatism, vol. 62, no. 5, pp. 1252-1258, 2010.

[21] Y.-J. Chen, Y.-T. Chang, C.-B. Wang, and C.-Y. Wu, "Malignancy in systemic lupus erythematosus: a nationwide cohort study 
in Taiwan," American Journal of Medicine, vol. 123, no. 12, pp. 1150.e1-1150.e6, 2010.

[22] L. K. Mercer, R. Davies, J. B. Galloway et al., "Risk of cancer in patients receiving non-biologic disease-modifying therapy for rheumatoid arthritis compared with the UK general population," Rheumatology, vol. 52, no. 1, pp. 91-98, 2013.

[23] L. Dreyer, L. Mellemkjær, A. R. Andersen et al., "Incidences of overall and site specific cancers in $\mathrm{TNF} \alpha$ inhibitor treated patients with rheumatoid arthritis and other arthritides-a follow-up study from the DANBIO Registry," Annals of the Rheumatic Diseases, vol. 72, no. 1, pp. 79-82, 2013.

[24] W. Zhang, S. Feng, S. Yan et al., "Incidence of malignancy in primary Sjögren's syndrome in a Chinese cohort," Rheumatology, vol. 49, no. 3, pp. 571-577, 2010.

[25] R. Solans-Laqué, A. López-Hernandez, J. Angel Bosch-Gil, A. Palacios, M. Campillo, and M. Vilardell-Tarres, "Risk, predictors, and clinical characteristics of lymphoma development in primary Sjögren's syndrome," Seminars in Arthritis and Rheumatism, vol. 41, no. 3, pp. 415-423, 2011.

[26] M.-Y. Weng, Y.-T. Huang, M.-F. Liu, and T.-H. Lu, "Incidence of cancer in a nationwide population cohort of 7852 patients with primary Sjögren's syndrome in Taiwan," Annals of the Rheumatic Diseases, vol. 71, no. 4, pp. 524-527, 2012.

[27] S. J. Johnsen, J. G. Brun, L. G. Gøransson et al., "Risk of non-Hodgkin's lymphoma in primary Sjogren's syndrome: a population-based study," Arthritis Care \& Research, vol. 65, no. 5, pp. 816-821, 2013.

[28] Y. Liang, Z. Yang, B. Qin, and R. Zhong, "Primary Sjögren's syndrome and malignancy risk: a systematic review and metaanalysis," Annals of the Rheumatic Diseases, vol. 73, no. 6, pp. 1151-1156, 2014.

[29] N. Feltelius, A. Ekbom, and P. Blomqvist, "Cancer incidence among patients with ankylosing spondylitis in Sweden 196595: a population based cohort study," Annals of the Rheumatic Diseases, vol. 62, no. 12, pp. 1185-1188, 2003.

[30] A. Shibata, S. Zhao, R. Makuch, J. Wentworth, J. Veith, and W. Wallis, "Lymphoma risk in ankylosing spondylitis patients is greater than that observed in the general population," Annals of the Rheumatic Diseases, vol. 63, supplement 1, p. 98, 2004.

[31] N. Becker, E. Deeg, T. Rüdiger, and A. Nieters, "Medical history and risk for lymphoma: results of a population-based casecontrol study in Germany," European Journal of Cancer, vol. 41, no. 1, pp. 133-142, 2005.

[32] J. Askling, L. Klareskog, P. Blomqvist, M. Fored, and N. Feltelius, "Risk for malignant lymphoma in ankylosing spondylitis: a nationwide Swedish case-control study," Annals of the Rheumatic Diseases, vol. 65, no. 9, pp. 1184-1187, 2006.

[33] L. Mellemkjaer, R. M. Pfeiffer, E. A. Engels et al., "Autoimmune disease in individuals and close family members and susceptibility to non-Hodgkin's lymphoma," Arthritis \& Rheumatism, vol. 58, no. 3, pp. 657-666, 2008.

[34] S. Rohekar, B. D. M. Tom, A. Hassa, C. T. Schentag, V. T. Farewell, and D. D. Gladman, "Prevalence of malignancy in psoriatic arthritis," Arthritis \& Rheumatism, vol. 58, no. 1, pp. 82-87, 2008.

[35] R. L. Gross, J. S. Schwartzman-Morris, M. Krathen et al., "A comparison of the malignancy incidence among patients with psoriatic arthritis and patients with rheumatoid arthritis in a large us cohort," Arthritis and Rheumatology, vol. 66, no. 6, pp. 1472-1481, 2014.

[36] O. Nived, A. Bengtsson, A. Jönsen, G. Sturfelt, and H. Olsson, "Malignancies during follow-up in an epidemiologically defined systemic lupus erythematosus inception cohort in southern Sweden,” Lupus, vol. 10, no. 7, pp. 500-504, 2001.

[37] J. Cibere, J. Sibley, and M. Haga, "Systemic lupus erythematosus and the risk of malignancy," Lupus, vol. 10, no. 6, pp. 394-400, 2001.

[38] L. Björnådal, B. Löfström, L. Yin, I. E. Lundberg, and A. Ekbom, "Increased cancer incidence in a Swedish cohort of patients with systemic lupus erythematosus," Scandinavian Journal of Rheumatology, vol. 31, no. 2, pp. 66-71, 2002.

[39] T. Tarr, B. Gyorfy, É. Szekanecz et al., "Occurrence of malignancies in Hungarian patients with systemic lupus erythematosus: results from a single center," Annals of the New York Academy of Sciences, vol. 1108, pp. 76-82, 2007.

[40] A. Parikh-Patel, R. H. White, M. Allen, and R. Cress, "Cancer risk in a cohort of patients with systemic lupus erythematosus (SLE) in California," Cancer Causes and Control, vol. 19, no. 8, pp. 887-894, 2008.

[41] K. Y. Kang, H. O. Kim, H. S. Yoon et al., "Incidence of cancer among female patients with systemic lupus erythematosus in Korea," Clinical Rheumatology, vol. 29, no. 4, pp. 381-388, 2010.

[42] L. Dreyer, M. Faurschou, M. Mogensen, and S. Jacobsen, "High incidence of potentially virus-induced malignancies in systemic lupus erythematosus: a long-term followup study in a Danish cohort," Arthritis and Rheumatism, vol. 63, no. 10, pp. 30323037, 2011.

[43] S. Bernatsky, R. Ramsey-Goldman, J. Labrecque et al., "Cancer risk in systemic lupus: an updated international multi-centre cohort study," Journal of Autoimmunity, vol. 42, pp. 130-135, 2013.

[44] C. L. Hill, Y. Zhang, B. Sigurgeirsson et al., "Frequency of specific cancer types in dermatomyositis and polymyositis: a population-based study," The Lancet, vol. 357, no. 9250, pp. 96100, 2001.

[45] D. Stockton, V. R. Doherty, and D. H. Brewster, "Risk of cancer in patients with dermatomyositis or polymyositis, and followup implications: a Scottish population-based cohort study," British Journal of Cancer, vol. 85, no. 1, pp. 41-45, 2001.

[46] G. Frentz and J. H. Olsen, "Malignant tumours and psoriasis: a follow-up study," British Journal of Dermatology, vol. 140, no. 2, pp. 237-242, 1999.

[47] P. Boffetta, G. Gridley, and B. Lindelöf, "Cancer risk in a population-based cohort of patients hospitalized for psoriasis in Sweden," Journal of Investigative Dermatology, vol. 117, no. 6, pp. 1531-1537, 2001.

[48] F. Wolfe and K. Michaud, "The effect of methotrexate and antitumor necrosis factor therapy on the risk of lymphoma in rheumatoid arthritis in 19,562 patients during 89,710 personyears of observation," Arthritis and Rheumatism, vol. 56, no. 5, pp. 1433-1439, 2007.

[49] P. Geborek, A. Bladström, C. Turesson et al., “Tumour necrosis factor blockers do not increase overall tumour risk in patients with rheumatoid arthritis, but may be associated with an increased risk of lymphomas," Annals of the Rheumatic Diseases, vol. 64, no. 5, pp. 699-703, 2005.

[50] J. Askling, C. M. Fored, E. Baecklund et al., "Haematopoietic malignancies in rheumatoid arthritis: lymphoma risk and characteristics after exposure to tumour necrosis factor antagonists," Annals of the Rheumatic Diseases, vol. 64, no. 10, pp. 1414-1420, 2005.

[51] S. Setoguchi, D. H. Solomon, M. E. Weinblatt et al., "Tumor necrosis factor $\alpha$ antagonist use and cancer in patients with 
rheumatoid arthritis," Arthritis and Rheumatism, vol. 54, no. 9, pp. 2757-2764, 2006.

[52] F. Wolfe and K. Michaud, "Lymphoma in rheumatoid arthritis: the effect of methotrexate and anti-tumor necrosis factor therapy in 18,572 patients," Arthritis and Rheumatism, vol. 50, no. 6, pp. 1740-1751, 2004.

[53] R. Buchbinder, M. Barber, L. Heuzenroeder et al., "Incidence of melanoma and other malignancies among rheumatoid arthritis patients treated with methotrexate," Arthritis Care \& Research, vol. 59, no. 6, pp. 794-799, 2008.

[54] B. Royer, D. Cazals-Hatem, J. Sibilia et al., "Lymphomas in patients with Sjogren's syndrome are marginal zone B-cell neoplasms, arise in diverse extranodal and nodal sites, and are not associated with viruses," Blood, vol. 90, no. 2, pp. 766-775, 1997.

[55] M. Voulgarelis, U. G. Dafni, D. A. Isenberg, and H. M. Moutsopoulos, "Malignant lymphoma in primary Sjogren's syndrome: a multicenter, retrospective, clinical study by the European concerted action on Sjogren's syndrome," Arthritis \& Rheumatism, vol. 42, no. 8, pp. 1765-1772, 1999.

[56] A. Ambrosetti, R. Zanotti, C. Pattaro et al., "Most cases of primary salivary mucosa-associated lymphoid tissue lymphoma are associated either with Sjoegren syndrome or hepatitis C virus infection," British Journal of Haematology, vol. 126, no. 1, pp. 43-49, 2004.

[57] S. M. Cohen, M. Petryk, M. Varma, P. S. Kozuch, E. D. Ames, and M. L. Grossbard, "Non-Hodgkin's lymphoma of mucosaassociated lymphoid tissue," Oncologist, vol. 11, no. 10, pp. 11001117, 2006.

[58] P. Youinou, V. Devauchelle-Pensec, and J.-O. Pers, "Significance of B cells and B cell clonality in Sjögren's syndrome," Arthritis and Rheumatism, vol. 62, no. 9, pp. 2605-2610, 2010.

[59] D. Cornec, V. Devauchelle-Pensec, G. J. Tobón, J.-O. Pers, S. Jousse-Joulin, and A. Saraux, "B cells in Sjögren's syndrome: from pathophysiology to diagnosis and treatment," Journal of Autoimmunity, vol. 39, no. 3, pp. 161-167, 2012.

[60] C. Dias and D. A. Isenberg, "Susceptibility of patients with rheumatic diseases to B-cell non-Hodgkin lymphoma," Nature Reviews Rheumatology, vol. 7, no. 6, pp. 360-368, 2011.

[61] S. Bernatsky, J. F. Boivin, L. Joseph et al., "An international cohort study of cancer in systemic lupus erythematosus," Arthritis and Rheumatism, vol. 52, no. 5, pp. 1481-1490, 2005.

[62] T. Okada, F. Takiura, K. Tokushige et al., "Major histocompatibility complex controls clonal proliferation of CD5+ B cells in H-2-congenic New Zealand mice: a model for B cell chronic lymphocytic leukemia and autoimmune disease," European Journal of Immunology, vol. 21, no. 11, pp. 2743-2748, 1991.

[63] A. Illes, L. Varoczy, G. Papp et al., "Aspects of B-cell nonHodgkin's lymphoma development: a transition from immunereactivity to malignancy," Scandinavian Journal of Immunology, vol. 69, no. 5, pp. 387-400, 2009.

[64] R. W. Hoffman, "T cells in the pathogenesis of systemic lupus erythematosus," Clinical Immunology, vol. 113, no. 1, pp. 4-13, 2004.

[65] Y. Zhang, T. R. Holford, B. Leaderer et al., "Prior medical conditions and medication use and risk of non-Hodgkin lymphoma in connecticut United States women," Cancer Causes and Control, vol. 15, no. 4, pp. 419-428, 2004.

[66] G. Gridley, J. H. Klippel, R. N. Hoover, and J. F. Fraumeni Jr., "Incidence of cancer among men with the Felty syndrome," Annals of Internal Medicine, vol. 120, no. 1, pp. 35-39, 1994.
[67] F. Wolfe, "Inflammatory activity, but not methotrexate or prednisone use predicts non-Hodgkin's lymphoma in rheumatoid arthritis: a 25-year study of 1,767 RA patients," Arthritis \& Rheumatology, vol. 41, no. 9, p. S188, 1998.

[68] M. Kauppi, E. Pukkala, and H. Isomäki, "Elevated incidence of hematologic malignancies in patients with Sjogren's syndrome compared with patients with rheumatoid arthritis (Finland)," Cancer Causes and Control, vol. 8, no. 2, pp. 201-204, 1997.

[69] E. Theander, G. Henriksson, O. Ljungberg, T. Mandl, R. Manthorpe, and L. T. H. Jacobsson, "Lymphoma and other malignancies in primary Sjögren's syndrome: A Cohort Study on Cancer Incidence and Lymphoma Predictors," Annals of the Rheumatic Diseases, vol. 65, no. 6, pp. 796-803, 2006.

[70] E. Baimpa, I. J. Dahabreh, M. Voulgarelis, and H. M. Moutsopoulos, "Hematologic manifestations and predictors of lymphoma development in primary Sjögren syndrome: clinical and pathophysiologic aspects," Medicine, vol. 88, no. 5, pp. 284-293, 2009.

[71] R. Solans-Laqué, A. López-Hernandez, J. A. Bosch-Gil, A. Palacios, M. Campillo, and M. Vilardell-Tarres, "Risk, predictors, and clinical characteristics of lymphoma development in primary Sjögren's syndrome," Seminars in Arthritis and Rheumatism, vol. 41, no. 3, pp. 415-423, 2011.

[72] L. Quartuccio, M. Isola, C. Baldini et al., "Biomarkers of lymphoma in Sjögren's syndrome and evaluation of the lymphoma risk in prelymphomatous conditions: results of a multicenter study," Journal of Autoimmunity, vol. 51, pp. 75-80, 2014.

[73] M. Ramos-Casals, P. Brito-Zerón, M. Perez-De-Lis et al., "Clinical and prognostic significance of parotid scintigraphy in 405 patients with primary Sjögren's syndrome," Journal of Rheumatology, vol. 37, no. 3, pp. 585-590, 2010.

[74] E. Theander, L. Vasaitis, E. Baecklund et al., "Lymphoid organisation in labial salivary gland biopsies is a possible predictor for the development of malignant lymphoma in primary Sjögren's syndrome," Annals of the Rheumatic Diseases, vol. 70, no. 8, pp. 1363-1368, 2011.

[75] M. J. Leandro and D. A. Isenberg, "Rheumatic diseases and malignancy-is there an association?" Scandinavian Journal of Rheumatology, vol. 30, no. 4, pp. 185-188, 2001.

[76] S. Bernatsky, R. Ramsey-Goldman, R. Rajan et al., "NonHodgkin's lymphoma in systemic lupus erythematosus," Annals of the Rheumatic Diseases, vol. 64, no. 10, pp. 1507-1509, 2005.

[77] S. Bernatsky, R. Ramsey-Goldman, L. Joseph et al., "Lymphoma risk in systemic lupus: effects of disease activity versus treatment," Annals of the Rheumatic Diseases, vol. 73, no. 1, pp. 138142,2013

[78] J. K. King and K. H. Costenbader, "Characteristics of patients with systemic lupus erythematosus (SLE) and non-Hodgkin's lymphoma (NHL)," Clinical Rheumatology, vol. 26, no. 9, pp. 1491-1494, 2007.

[79] B. Löfström, C. Backlin, C. Sundström, A. Ekbom, and I. E. Lundberg, "A closer look at non-Hodgkin's lymphoma cases in a national Swedish systemic lupus erythematosus cohort: a nested case-control study," Annals of the Rheumatic Diseases, vol. 66, no. 12, pp. 1627-1632, 2007.

[80] S. Bernatsky, L. Joseph, J.-F. Boivin et al., "The relationship between cancer and medication exposures in systemic lupus erythaematosus: a case-cohort study," Annals of the Rheumatic Diseases, vol. 67, no. 1, pp. 74-79, 2008.

[81] B. Sigurgeirsson, B. Lindelöf, O. Edhag, and E. Allander, "Risk of cancer in patients with dermatomyositis or polymyositis," The 
New England Journal of Medicine, vol. 326, no. 6, pp. 363-367, 1992.

[82] J. M. Gelfand, D. B. Shin, A. L. Neimann, X. Wang, D. J. Margolis, and A. B. Troxel, "The risk of lymphoma in patients with psoriasis," Journal of Investigative Dermatology, vol. 126, no. 10, pp. 2194-2201, 2006.

[83] C. G. Mullighan, S. Heatley, S. Lester, M. Rischmueller, T. P. Gordon, and P. G. Bardy, "Fas gene promoter polymorphisms in primary Sjögren's syndrome," Annals of the Rheumatic Diseases, vol. 63, no. 1, pp. 98-101, 2004.

[84] Y. Yoshida, Y. Takahashi, H. Yamashita, T. Kano, H. Kaneko, and A. Mimori, "Clinical characteristics and incidence of methotrexate-related lymphoproliferative disorders of patients with rheumatoid arthritis," Modern Rheumatology, vol. 24, no. 5, pp. 763-765, 2014.

[85] K. Ikeda, T. Nakamura, T. Kinoshita et al., "Methotrexaterelated lymphoproliferative disorder of the stomach in a patient with rheumatoid arthritis: a case of disease regression after methotrexate cessation," Clinical Journal of Gastroenterology, vol. 9, no. 1, pp. 17-21, 2016.

[86] Y. Hoshida, J.-X. Xu, S. Fujita et al., "Lymphoproliferative disorders in rheumatoid arthritis: clinicopathological analysis of 76 cases in relation to methotrexate medication," Journal of Rheumatology, vol. 34, no. 2, pp. 322-331, 2007.

[87] E. Salloum, D. L. Cooper, G. Howe et al., "Spontaneous regression of lymphoproliferative disorders in patients treated with methotrexate for rheumatoid arthritis and other rheumatic diseases," Journal of Clinical Oncology, vol. 14, no. 6, pp. 19431949, 1996.

[88] C. Salliot and D. van der Heijde, "Long-term safety of methotrexate monotherapy in patients with rheumatoid arthritis: a systematic literature research," Annals of the Rheumatic Diseases, vol. 68, no. 7, pp. 1100-1104, 2009.

[89] A. Kandiel, A. G. Fraser, B. I. Korelitz, C. Brensinger, and J. D. Lewis, "Increased risk of lymphoma among inflammatory bowel disease patients treated with azathioprine and 6mercaptopurine," Gut, vol. 54, no. 8, pp. 1121-1125, 2005.

[90] T. Bongartz, A. J. Sutton, M. J. Sweeting, I. Buchan, E. L. Matteson, and V. Montori, "Anti-TNF antibody therapy in rheumatoid arthritis and the risk of serious infections and malignancies: Systematic review and meta-analysis of rare harmful effects in randomized controlled trials," Journal of the American Medical Association, vol. 295, no. 19, pp. 2275-2285, 2006.

[91] S. L. Brown, M. H. Greene, S. K. Gershon, E. T. Edwards, and M. M. Braun, "Tumor necrosis factor antagonist therapy and lymphoma development: twenty-six cases reported to the Food and Drug Administration," Arthritis and Rheumatism, vol. 46, no. 12, pp. 3151-3158, 2002.

[92] D. A. Clark, "Do anti-TNF- $\alpha$ drugs increase cancer risk in rheumatoid arthritis patients?" Inflammopharmacology, vol. 21, no. 2, pp. 125-127, 2013.

[93] R. Midgard, E. Glattre, M. Grønning, T. Riise, A. Edland, and H. Nyland, "Multiple sclerosis and cancer in Norway a retrospective cohort study," Acta Neurologica Scandinavica, vol. 93, no. 6, pp. 411-415, 1996.

[94] M.-L. Sumelahti, E. Pukkala, and M. Hakama, "Cancer incidence in multiple sclerosis: a 35-year follow-up," Neuroepidemiology, vol. 23, no. 5, pp. 224-227, 2004.

[95] L. Wideroff, G. Gridley, L. Mellemkjaer et al., "Cancer incidence in a population-based cohort of patients hospitalized with diabetes mellitus in Denmark," Journal of the National Cancer Institute, vol. 89, no. 18, pp. 1360-1365, 1997.
[96] K. Zendehdel, O. Nyrén, C.-G. ÖStenson, H.-O. Adami, A. Ekbom, and W. Ye, "Cancer incidence in patients with type 1 diabetes mellitus: a population-based cohort study in Sweden," Journal of the National Cancer Institute, vol. 95, no. 23, pp. 17971800, 2003.

[97] J. Askling, J. Grunewald, A. Eklund, G. Hillerdal, and A. Ekbom, "Increased risk for cancer following sarcoidosis," American Journal of Respiratory and Critical Care Medicine, vol. 160, no. 5, part 1, pp. 1668-1672, 1999.

[98] F. K. Rømer, P. Hommelgaard, and G. Schou, "Sarcoidosis and cancer revisited: a long-term follow-up study of 555 Danish sarcoidosis patients," European Respiratory Journal, vol. 12, no. 4, pp. 906-912, 1998.

[99] N. Seersholm, J. Vestbo, and K. Viskum, "Risk of malignant neoplasms in patients with pulmonary sarcoidosis," Thorax, vol. 52, no. 10, pp. 892-894, 1997.

[100] C. S. Hampe, "B cells in autoimmune diseases," Scientifica, vol. 2012, Article ID 215308, 18 pages, 2012.

[101] M. Libra, D. Gasparotto, A. Gloghini, P. M. Navolanic, V. De $\mathrm{Re}$, and A. Carbone, "Hepatitis C virus (HCV) infection and lymphoproliferative disorders," Frontiers in Bioscience, vol. 10, no. 2, pp. 2460-2471, 2005.

[102] L. Arcaini, S. Burcheri, A. Rossi et al., "Prevalence of HCV infection in nongastric marginal zone B-cell lymphoma of MALT,' Annals of Oncology, vol. 18, no. 2, pp. 346-350, 2007.

[103] T. M. Gibson, K. E. Smedby, C. F. Skibola et al., "Smoking, variation in $\mathrm{N}$-acetyltransferase 1 (NAT1) and 2 (NAT2), and risk of non-Hodgkin lymphoma: a pooled analysis within the InterLymph consortium," Cancer Causes and Control, vol. 24, no. 1, pp. 125-134, 2013.

[104] S. Ekblom-Kullberg, H. Kautiainen, P. Alha, M. Leirisalo-Repo, and H. Julkunen, "Smoking and the risk of systemic lupus erythematosus," Clinical Rheumatology, vol. 32, no. 8, pp. 12191222, 2013.

[105] T. N. Sergentanis, P. Kanavidis, T. Michelakos, and E. T. Petridou, "Cigarette smoking and risk of lymphoma in adults: a comprehensive meta-analysis on Hodgkin and non-Hodgkin disease," European Journal of Cancer Prevention, vol. 22, no. 2, pp. 131-150, 2013.

[106] K. Lundberg, C. Bengtsson, N. Kharlamova et al., "Genetic and environmental determinants for disease risk in subsets of rheumatoid arthritis defined by the anticitrullinated protein/peptide antibody fine specificity profile," Annals of the Rheumatic Diseases, vol. 72, no. 5, pp. 652-658, 2013.

[107] T. R. Mikuls, J. O. Endo, S. E. Puumala et al., "Prospective study of survival outcomes in non-Hodgkin's lymphoma patients with rheumatoid arthritis," Journal of Clinical Oncology, vol. 24, no. 10, pp. 1597-1602, 2006.

[108] M. Ehrenfeld, M. Abu-Shakra, D. Buskila, and Y. Shoenfeld, "The dual association between lymphoma and autoimmunity," Blood Cells, Molecules, and Diseases, vol. 27, no. 4, pp. 750-756, 2001. 


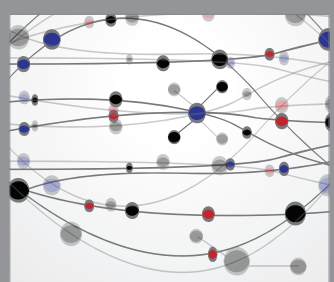

The Scientific World Journal
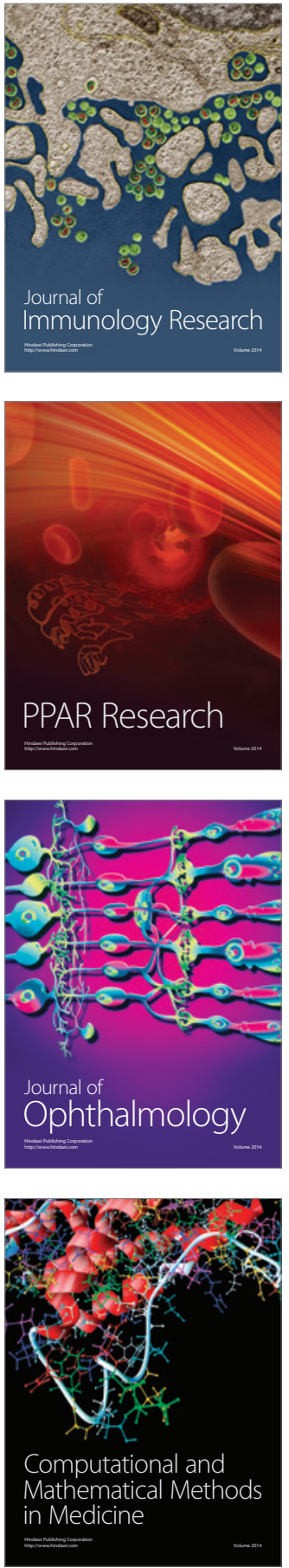

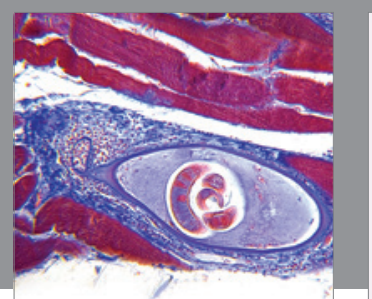

Gastroenterology Research and Practice

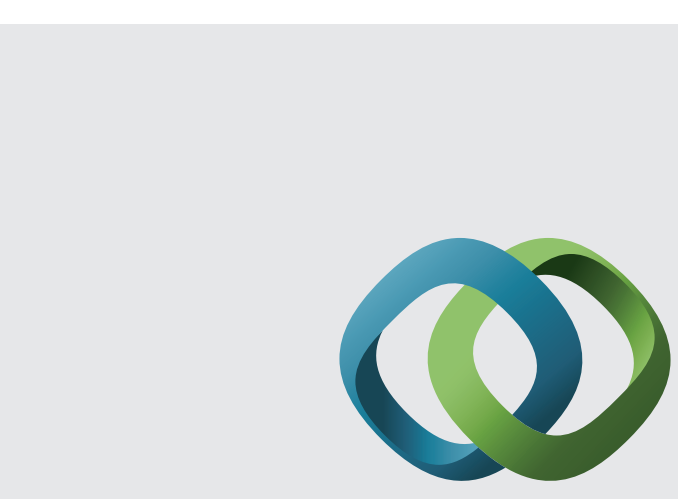

\section{Hindawi}

Submit your manuscripts at

http://www.hindawi.com
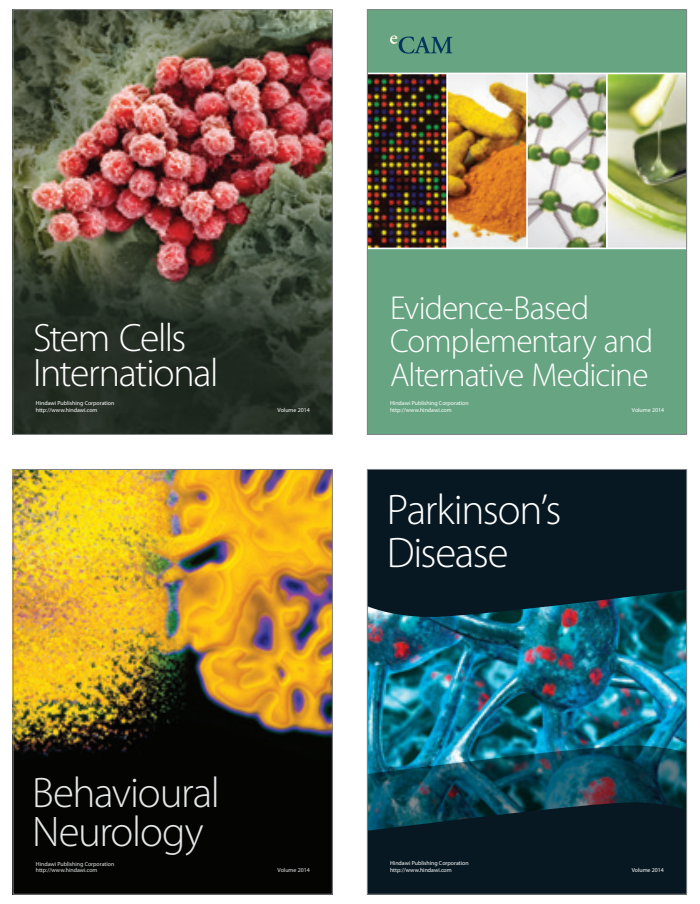
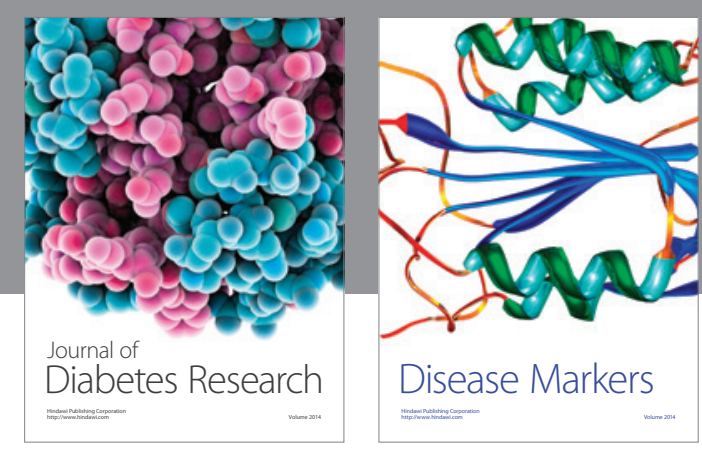

Disease Markers
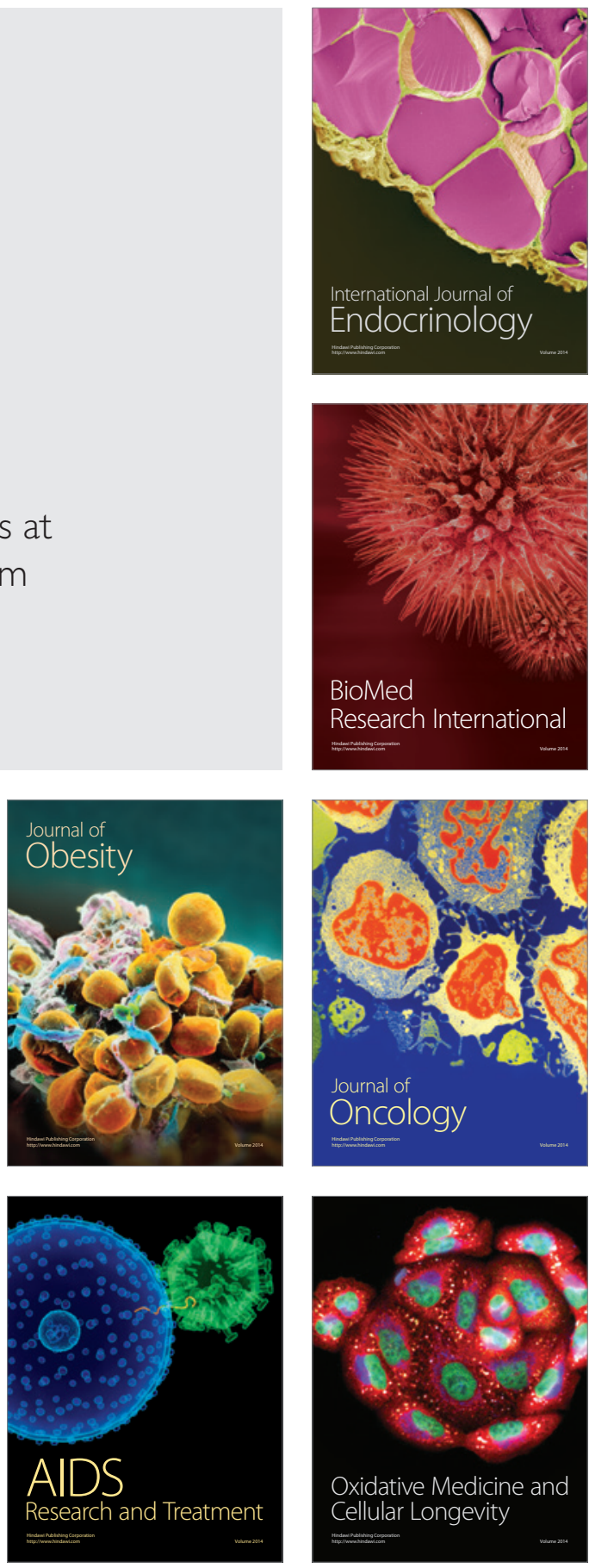